\title{
ENVIRONMENTAL ACTIVITY-BASED COSTING AS AN INSTRUMENT OF ENVIRONMENTAL MANAGEMENT ACCOUNTING
}

\author{
Ljilja Antić1 \\ Faculty of Economics, University of Niš, Serbia \\ Tatjana Stevanović ${ }^{2}$ \\ Faculty of Economics, University of Niš, Serbia \\ Jovana Milenović ${ }^{3}$ \\ Faculty of Economics, University of Niš, Serbia
}

\begin{abstract}
The issue of environmental protection has become increasingly important throughout the world in recent decades. Spreading awareness of the quality of the environment should not be sought only in the application of eco-technologies, but also in environmental ethics, because without it there is no human survival and preservation of the environment. Environmental management accounting plays an important role in the environmental management process, the aim of which is to provide relevant information to all stakeholders. Also, environmental management accounting improves resource efficiency and makes it easier for company managers to make decisions on the project that will help improve environmental performance. The aim of this paper is to point out the importance and need for environmental activity-based costing as an instrument of environmental management accounting

Keywords: environmental management accounting, environmental activity-based costing, environmental protection
\end{abstract}

\section{INTRODUCTION}

Industrial and technological development has brought about changes both in nature and in company operations. Today, most countries in the world strive to ensure a healthy life and do business in a healthy environment. In order to meet these requirements, it is necessary to include the environmental business dimension in conventional management accounting, which leads to the emergence of environmental management accounting.

Environmental costs are very often hidden in the company and are difficult to identify. Therefore, companies should focus their efforts on

\footnotetext{
${ }^{1}$ 1jilja.antic@eknfak.ni.ac.rs

2 tatjana.stevanovic@eknfak.ni.ac.rs

${ }^{3}$ milenovicjovana@gmail.com

The paper is the result of research based on obligations under the Agreement on the implementation and financing of research and development in 2020 (record number 45103-68/2020-14/200100), concluded between the Ministry of Education, Science and Technological Development of the Republic of Serbia and the Faculty of Economics University of Niš.
} 
recognizing environmental costs, because timely cost identification and management leads to their reduction, but also to the reduction of the negative impact on the environment. Effective environmental cost management facilitates business decisions in the company and helps increase environmental performance. In this regard, in order to provide adequate information on environmental costs, the company must have an appropriate costing system.

The paper is structured in three parts. In the first part of the paper, the focus is on the importance of Environmental Management Accounting (EMA) information. The second part of the paper will discuss the methodology of environmental activity-based costing (EABC). The third part of the paper deals with advantages and disadvantages of applying environmental activity-based costing.

\section{SIGNIFICANCE OF ENVIRONMENTAL MANAGEMENT ACCOUNTING INFORMATION}

The need to plan, monitor, record and report on investment in environmental protection arises from environmental protection requirements. Problems that affect the preservation of the environment, such as climate change, irrational water consumption, land dehydration, etc., can be observed from various perspectives. The companies' sustainable development goals refer to the establishment of a system that will balance economic development with responsible consumption of resources and better protection of the environment (Sekerez, 2016, p.55). Environmental management is based on the following concepts (Jovanović \& Ljubisavljević, 2017, p.525):

- Sustainable development - development that meets the needs of present generations without compromising the ability of future generations to meet their own needs. Sustainable development includes economic, environmental and social sustainability. Companies pay more and more attention to sustainable development in order to achieve a competitive advantage.

- Eco-efficiency - is achieved by delivering products and services at competitive prices that meet human needs and contribute to quality of life, while gradually reducing environmental impacts and resource intensity during the life cycle to a level consistent with the earth's estimated carrying capacity (Schaltegger \& Burritt, 2000, p.49).

- Cleaner production - represents the application of a comprehensive environmental strategy in production 
processes, products and services with the aim of increasing overall efficiency and reducing risks to human health and the environment.

Focusing on environmental protection and sustainable development has led to the emergence of a more flexible management instrument, the so-called environmental management accounting (EMA), which provides more accurate information for making business decisions compared to conventional management accounting. Criticisms of conventional management accounting regarding the treatment of environmental costs can be categorized as follows (Burritt, 2004, p.15):

- It is assumed that the costs of environmental protection are not significant;

- Overhead costs of environmental protection are included in overhead operating costs;

- Performance measurement techniques are too narrow and short-term oriented;

- Environmental issues are not included in investment estimates;

- Narrow focus on production;

- Dominance of financial and accounting rules and

- Absence of accounting for externalities.

Environmental management accounting is a comprehensive approach that aims to enable quality decision-making regarding environmental issues (Gray \& Bebbington, 2001). The International Federation of Accountants defines environmental management accounting as the management of environmental and economic performance through the development and application of appropriate accounting systems and practices related to environmental protection. Environmental management accounting includes life cycle costing, full cost accounting, benefit assessment, and strategic environmental management planning. In addition to those listed in the literature, there are other definitions where there is no generally accepted and universal definition of EMA, but all of them more or less indicate the same essence.

The development of environmental management accounting began in the last decade of the twentieth century. Corporate governance mechanisms and ethical guidelines influence management accounting to report on the impact of a company's business on the environment, but also to report on environmental performance. The emergence of corporate social responsibility (CSR) guidelines and the emergence of ISO 14000 standards contribute to better financial reporting and better assessment of environmental costs. Also, the development of science has improved the production process and a more rational use of resources. Two approaches to the development of EMA are cited in the literature (Cullen, 2006, p.3): 
- Conservative approach - the main goal of the conservative approach is to integrate environmental protection into the company's strategy. The approach encourages companies to use resources more efficiently in order to reduce the negative impact on the environment. The UN Expert Working Group, the International Federation of Accountants and other international bodies support a conservative approach. These bodies point out that companies need to identify environmental costs in order to manage them more easily.

- Critical approach - is an approach broader than conservative, because it includes environmental responsibility and sustainability plan, considers the role and responsibility of accounting in improving the sustainability plan and requires a multidisciplinary approach. The focus of the critical approach is to internalize external costs.

EMA is a new concept, still incompletely explored, but it is increasingly becoming a subject and a need of companies and the broader scientific community. It is a very useful tool that allows overcoming the limitations of conventional management accounting, provides financial and non-financial information that helps managers in the company in making business decisions. The EMA enables companies to more easily and simply identify environmental costs, manage them, report on their environmental impacts and improve their reputation in society.

Environmental costs are becoming an increasingly important cost category. There are numerous definitions and classifications of environmental costs. In some countries, environmental costs are legally determined or include the costs of labor and equipment aimed at protecting the environment. Environmental costs are associated with the creation, detection, remediation, and prevention of environmental deregulation (Hansen \& Mowen, 2003, p. 497). Looking at environmental costs from an activity type perspective, there are (Hansen \& Mowen 2003, p.495):

- Environmental prevention costs - costs incurred to prevent production that may adversely affect the protection of the environment. Prevention activities include: evaluation and selection of suppliers, process design, product design, environmental risk audit, development of environmental management systems, etc.

- Environmental detection costs - costs of activities undertaken to determine whether products and processes comply with environmental standards. Detection activities are: inspection of 
products and processes, development of environmental performance measures, measurement of pollution levels.

- Environmental internal failure costs - costs incurred to prevent pollutants and waste from being released into the environment, i.e. to bring their levels in line with standards. The internal failure activities are: testing and disposal of toxic waste, maintenance of equipment that causes pollution, operation of pollution control equipment and waste recycling.

- Environmental external failure costs - costs of activities performed after the release of pollutants and hazardous waste into the environment. These costs may be borne by the company or by the society. Examples of external failure activities are: cleaning of polluted lakes, cleaning of contaminated land, restoring the land to its original condition, medical assistance due to polluted air and loss of lakes for recreational use.

If environmental costs are not singled out as a separate category, but are aggregated with overhead costs, it can happen that "dirtier" products are sold at lower prices, and environmentally "cleaner" products at higher prices (Jugović, 2019, p.51). This cost treatment in the traditional costing system has the following negative consequences (Radukić \& Stevanović, 2011, p.112):

- Inadequate cost allocation at different levels;

- Incorrect pricing of products and services;

- Distorted scheme of remuneration (salaries) and compensation for employees;

- Inadequate capital budgeting and investment assessment;

- Inadequate production mix and

- Inability to effectively implement cost reduction measures.

Environmental management accounting enables the provision of information of a financial and non-financial nature. Non-financial information refers to physical environmental management accounting while financial information refers to the monetary environmental management accounting (MEMA). This information is of primary importance in managing costs and reducing the negative impact of the company's operations on the environment. The company has at its disposal two categories of EMA instruments that it can use when managing environmental costs (Radukić \& Stevanović, 2011, p. 119). The first category refers to cost management instruments and the second to resource management instruments. An overview of the categories is given in Figure 1. 
Figure 1.: EMA Instruments
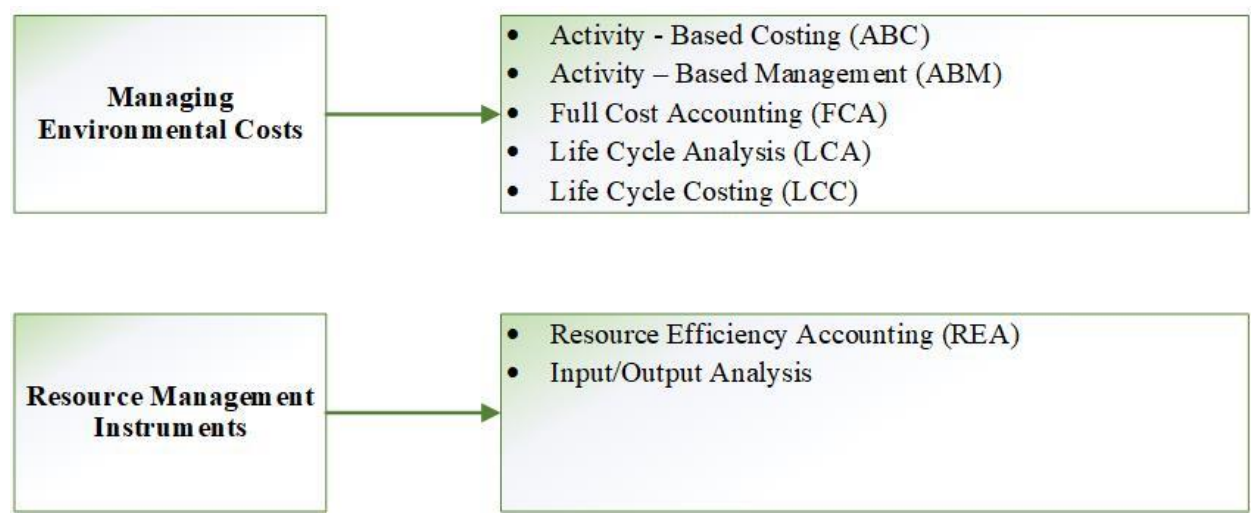

Source: Adapted from: Radukić, S., \& Stevanović, T. (2011). Ekološki zahtevi i njihov računovodstveni tretman. Ekonomske teme, 49(1).

Activity-based management $(\mathrm{ABM})$ is an integral approach to managing business activities. ABM information support comes from activity-based costing. ABM has two main goals (Cokins, 1999, p.31): cost allocation, cost pricing, and measuring product profitability as the first goal, measuring activity performance, and analyzing it as the second goal. ABM strives to redesign the company's business processes, which eliminates activity cost drivers that do not add value.

Full cost accounting (FCA) is a conventional costing method used to determine total production costs. When allocating costs to a product, this method monitors direct costs and allocated indirect product costs.

Life Cycle Analysis (LCA) involves identifying activities throughout the life cycle and provides opportunities for business improvement. This method allows for a more complete assessment of the company's costs and impact on the environment. The analysis includes the impact of production on the environment and provides the required level of confidentiality and copyright.

Life cycle costing (LCC) is a method that accumulates the costs of an individual value chain. Therefore, it connects with the product all the costs that occur during the lifetime, from the purchase of raw materials to the disposal of waste. This method allows for a more complete assessment of the company's costs and impact on the environment.

Resource efficiency accounting (REA) collects material data over the product life cycle and defines the corresponding costs within the enterprise. REA uses existing costing systems and allows for the assessment of economic and environmental performance. 
Input/output analysis shows the production process in the country and enables the determination of mutual relations and dependence of individual activities in the production process (Bilbilovska, 2015, p.127). This analysis enables the determination of multiplicative effects of final consumption on production, employment, price interdependence, etc. Production costs occur as inputs, and a product or service represents an output. The goal of input/output analysis is to show the creation and distribution of final production.

\section{ENVIRONMENTAL ACTIVITY-BASED COSTING}

Environmental Activity Based Costing (EABC) improves traditional costing. The information on activities and cost objects produced in this way also improves the company's performance. Environmental activitybased costing methodology includes (Schaltegger \& Burritt, 2000, p.63):

- Identification of consumption objects (products, services, markets, sales channels, customers, parts of companies, etc.);

- Identification of activity pools (related environmental activities by cost structure they cause);

- Identification of cost pools (reclassification of overheads by type to activity from activity pools);

- Identification of cost drivers such as product quantities, machine hours, control hours, number of transactions, tons, etc.;

- Costing per unit of cost driver, i.e. calculation of cost rates or quotas and

- Allocating overhead costs to objects, in proportion to the activities and the number of drivers.

As environmental costs belong to overhead costs, activity-based costing allows tracking environmental costs by products and activities using cost drivers. An important step in applying the method is to identify the drivers of resource consumption in order to allocate costs to each activity, which means compiling a list of activities. An example of a detailed list of activities that cause environmental costs and their drivers is given in Table 1.

Table 1.: List of activities that cause environmental

\begin{tabular}{|c|c|c|c|}
\hline $\begin{array}{l}\text { Activity } \\
\text { centre }\end{array}$ & Environmental activity & Resources & Activity driver \\
\hline $\begin{array}{c}\text { Pollution } \\
\text { prevention } \\
\text { activity centre }\end{array}$ & 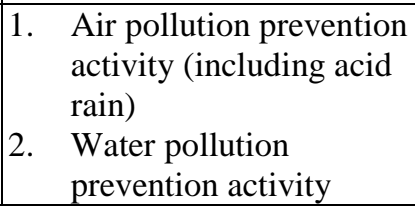 & $\begin{array}{l}\text { Equipment, } \\
\text { labour, } \\
\text { utility } \\
\text { Equipment, } \\
\text { labour, }\end{array}$ & $\begin{array}{l}\text { Volume of waste } \\
\text { emissions }(\mathrm{kg}) \\
\text { Volume of waste } \\
\text { water }\left(\mathrm{m}^{3}\right) \\
\text { Volume of }\end{array}$ \\
\hline
\end{tabular}

Vol. 23, број 1/2021, cmp. 53-68 


\begin{tabular}{|c|c|c|c|}
\hline & 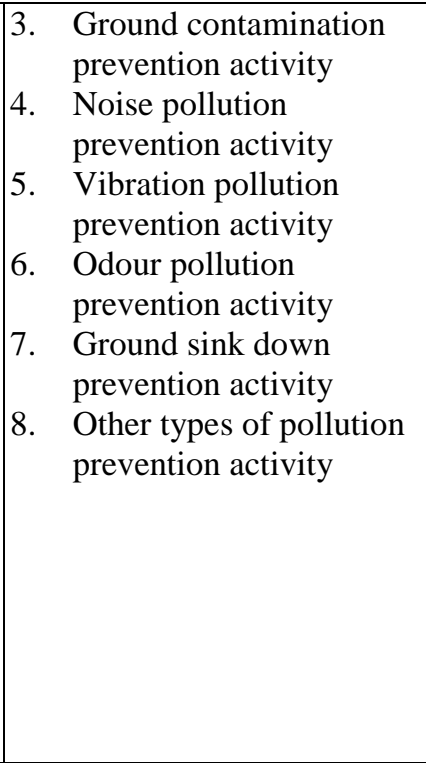 & $\begin{array}{l}\text { utility } \\
\text { Equipment, } \\
\text { labour, } \\
\text { utility } \\
\text { Equipment, } \\
\text { labour, } \\
\text { utility } \\
\text { Equipment, } \\
\text { labour, } \\
\text { utility } \\
\text { Equipment, } \\
\text { labour, } \\
\text { utility } \\
\text { Equipment, } \\
\text { labour, } \\
\text { utility } \\
\text { Equipment, } \\
\text { labour, } \\
\text { utility }\end{array}$ & 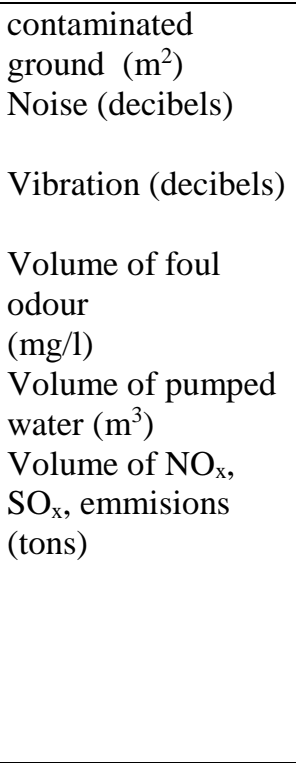 \\
\hline $\begin{array}{c}\text { Global } \\
\text { environmental } \\
\text { conservation } \\
\text { activity centre }\end{array}$ & 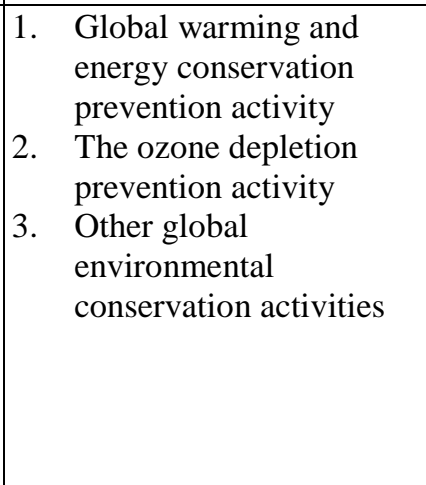 & $\begin{array}{l}\text { Equipment, } \\
\text { labour, } \\
\text { utility } \\
\text { Equipment, } \\
\text { labour, } \\
\text { utility } \\
\text { Equipment, } \\
\text { labour, } \\
\text { utility }\end{array}$ & $\begin{array}{l}\text { Volume of } \\
\text { greenhouse gas } \\
\text { emissions (tons- } \\
\mathrm{CO}_{2} \text { ) } \\
\text { Volume of } \\
\text { greenhouse gas } \\
\text { emissions (tons- } \\
\mathrm{CO}_{2} \text { ) } \\
\text { Volume of } \\
\text { greenhouse gas } \\
\text { emissions (tons- } \\
\mathrm{CO}_{2} \text { ) }\end{array}$ \\
\hline $\begin{array}{c}\text { Resource } \\
\text { recycling } \\
\text { activity centre }\end{array}$ & \begin{tabular}{|l} 
1. \\
Activity for the efficient \\
utilization of resources \\
Activity for recycling \\
industrial waste \\
3. $\begin{array}{l}\text { Activity for recycling } \\
\text { hazardous waste }\end{array}$ \\
4. $\begin{array}{l}\text { Activity for disaposal of } \\
\text { industrial waste }\end{array}$ \\
5. $\begin{array}{l}\text { Activity for disaposal of } \\
\text { hazardous waste } \\
\text { Activity contributing to } \\
\text { resource circulation }\end{array}$
\end{tabular} & $\begin{array}{l}\text { Equipment, } \\
\text { labour, } \\
\text { utility } \\
\text { Equipment, } \\
\text { labour, } \\
\text { utility } \\
\text { Equipment, } \\
\text { labour, } \\
\text { utility } \\
\text { Equipment, } \\
\text { labour, } \\
\text { utility } \\
\text { Equipment, } \\
\text { labour, } \\
\text { utility } \\
\text { Equipment, } \\
\text { labour, } \\
\text { utility }\end{array}$ & $\begin{array}{l}\text { Total energy input } \\
\text { volume (joules) } \\
\text { Volume of recycled } \\
\text { industrial waste } \\
\text { (tons) } \\
\text { Volume of recycled } \\
\text { hazardous waste } \\
\text { (tons) } \\
\text { Volume of non- } \\
\text { recycled industrial } \\
\text { waste (tons) } \\
\text { Volume of non- } \\
\text { recycled hazardous } \\
\text { waste (tons) } \\
\text { Input volume of } \\
\text { circulated resources } \\
\text { (tons) }\end{array}$ \\
\hline Social activity & 1. Activity for & None & Distribute \\
\hline
\end{tabular}




\begin{tabular}{|c|c|c|c|c|}
\hline centre & & $\begin{array}{l}\text { environmental } \\
\text { improvement activities, } \\
\text { including nature } \\
\text { conservation, planting of } \\
\text { greenery, beautification } \\
\text { and landscape } \\
\text { preservation, with the } \\
\text { sxception of the business } \\
\text { site } \\
\text { Activity related to } \\
\text { donation or financial } \\
\text { support of environmental } \\
\text { groups } \\
\text { Activity associated with } \\
\text { various social activities, } \\
\text { such as the financial } \\
\text { support of a local } \\
\text { community's } \\
\text { environmental } \\
\text { conservation activities } \\
\text { and the disclosure of } \\
\text { information to the local } \\
\text { community }\end{array}$ & $\begin{array}{l}\text { None } \\
\text { None }\end{array}$ & $\begin{array}{l}\text { Distribute } \\
\text { proportionally to all } \\
\text { business units based } \\
\text { on revenue (dollars) } \\
\text { Distribute } \\
\text { proportionally to all } \\
\text { business units based } \\
\text { on revenue (dollars) }\end{array}$ \\
\hline $\begin{array}{l}\text { Environmental } \\
\text { remediation } \\
\text { activity centre }\end{array}$ & & $\begin{array}{l}\text { Activity to restore the } \\
\text { natural environment back } \\
\text { to its original state } \\
\text { Activity to cover } \\
\text { degradation suits } \\
\text { connected with } \\
\text { environmental } \\
\text { conservation } \\
\text { Provisions or insurance } \\
\text { fees to cover degradation } \\
\text { to the environment }\end{array}$ & $\begin{array}{l}\text { Labour, } \\
\text { material } \\
\text { Labour } \\
\text { None }\end{array}$ & $\begin{array}{l}\begin{array}{l}\text { Volume of } \\
\text { contaminated } \\
\text { ground }\left(\mathrm{m}^{2}\right)\end{array} \\
\text { Volume of waste } \\
\text { emissions (tons) } \\
\begin{array}{l}\text { Number of incidents } \\
\text { (no.) }\end{array}\end{array}$ \\
\hline
\end{tabular}

Source: Adapted from: Tsai, W-H., Lin, T., \& Chou, W-C. (2010). Integrating activitybased costing and environmental cost accounting systems: a case study. International Journal of Business and Systems Research, 4(2).

In a customized example, we will show how environmental costs are allocated to product " $C$ " and product " $D$ " using activity-based costing (example adapted from Hansen \& Mowen, 2003 i Tsai et al., 2010).

"Alfa" produces two products, C and D. The production volume of product "C" is 50,000 units, and product " $\mathrm{D}$ " is 65,000 units. The consumption of resources is caused by various activities that take place within the organizational parts of the company. An overview of environmental protection activities performed during the production process and their costs is given in Table 2. 
Table 2.: Environmental protection activities and their costs at enterprise "Alfa"

\begin{tabular}{|c|c|c|}
\hline $\begin{array}{c}\text { Activity } \\
\text { categories }\end{array}$ & Activity & $\begin{array}{c}\text { Cost activity } \\
(\mathbf{m . u .})^{*}\end{array}$ \\
\hline $\begin{array}{l}\text { Pollution } \\
\text { prevention } \\
\text { activity }\end{array}$ & $\begin{array}{l}\text { - Water pollution prevention activity } \\
\text { - Ground sink down prevention } \\
\text { activity }\end{array}$ & 120,000 \\
\hline $\begin{array}{c}\text { Social } \\
\text { activities }\end{array}$ & $\begin{array}{l}\text { Activity related to donation or financial } \\
\text { support of environmental groups } \\
\text { Activity related to various social } \\
\text { activities such as financial support to the } \\
\text { local community }\end{array}$ & 60,000 \\
\hline $\begin{array}{l}\text { Resource } \\
\text { recycling } \\
\text { activity }\end{array}$ & $\begin{array}{l}\text { - Activity for recycling industrial } \\
\text { waste } \\
\text { - Activity for disposal of hazardous } \\
\text { waste }\end{array}$ & 360,000 \\
\hline $\begin{array}{l}\text { Environmental } \\
\text { remediation } \\
\text { activities }\end{array}$ & $\begin{array}{l}\text { Activity to restore the natural } \\
\text { environment back to its original state }\end{array}$ & 180,000 \\
\hline
\end{tabular}

If a resource is necessary to perform only one activity then it is easy to attribute the resource cost to that activity. In case the resource is necessary to perform several activities at the same time, then the part of the resource costs that will be allocated to the activities is determined by resource consumption driver. Allocation of costs from activities to cost objects, i.e. to products "C" and " $\mathrm{D}$ " is performed using activity drivers. An overview of activity drivers is given in Table 3.

Table 3.: Activity drivers

\begin{tabular}{|c|c|c|c|c|}
\hline $\begin{array}{c}\text { Activity } \\
\text { categories }\end{array}$ & Cost driver & $\begin{array}{c}\text { Activity } \\
\text { driver level for } \\
\text { product "C" }\end{array}$ & $\begin{array}{c}\text { Activity } \\
\text { driver level for } \\
\text { product "D" }\end{array}$ & $\begin{array}{c}\text { Total } \\
\text { activity } \\
\text { driver level }\end{array}$ \\
\hline $\begin{array}{c}\text { Pollution } \\
\text { prevention } \\
\text { activity }\end{array}$ & Amount of waste ( $\left.\mathrm{m}^{3}\right)$ & 1,500 & 1,200 & 2,700 \\
\hline Social activities & $\begin{array}{c}\text { Financial support to } \\
\text { social groups (m.u.)* }\end{array}$ & 1,000 & 2,400 & 3,400 \\
\hline $\begin{array}{c}\text { Resource } \\
\text { recycling activity }\end{array}$ & Amount of waste (t) & 30,000 & 45,000 & 75,000 \\
\hline $\begin{array}{c}\text { Environmental } \\
\text { remediation } \\
\text { activities }\end{array}$ & Pollution level (m²) & 150,000 & 225,000 & 375,000 \\
\hline
\end{tabular}

*m.u. - monetary units

Source: Authors 
Table 4 shows the rate of activity drivers. The rate of activity drivers is the ratio of the cost of activity and the level of activity driver. The rate of the pollution prevention driver is $44.44 \mathrm{~m} . \mathrm{u} . / \mathrm{m} 3$, and is a quotient of 120,000 m.u. (costs of pollution prevention activities) and $2,700 \mathrm{~m}^{3}$ (total level of activity drivers).

Table 4.: The rate of activity drivers

\begin{tabular}{|l|c|c|c|}
\hline \multicolumn{1}{|c|}{ Activity categories } & $\begin{array}{c}\text { Costs } \\
\text { activity }\end{array}$ & $\begin{array}{c}\text { Total } \\
\text { activity } \\
\text { driver level }\end{array}$ & $\begin{array}{c}\text { Rate of } \\
\text { activity } \\
\text { drivers }\end{array}$ \\
\hline Pollution prevention activity & 120,000 & 2,700 & 44.44 \\
\hline Social activities & 60,000 & 3,400 & 17.65 \\
\hline Resource recycling activity & 360,000 & 75,000 & 4.8 \\
\hline Environmental remediation activities & 180,000 & 375,000 & 0.48 \\
\hline
\end{tabular}

Source: Authors

Using the activity drivers in Table 5, we allocate activity costs to product " $C$ " and product " $\mathrm{D}$ ".

Table 5.: Allocate activity costs to the cost object

\begin{tabular}{|c|c|c|c|c|c|}
\hline \multirow[b]{2}{*}{ Activity } & \multirow[b]{2}{*}{$\begin{array}{c}\text { Rate of activity } \\
\text { drivers }\end{array}$} & \multicolumn{2}{|c|}{ Product ,C66 } & \multicolumn{2}{|c|}{ Product,,D“6 } \\
\hline & & $\begin{array}{c}\text { Driver } \\
\text { level }\end{array}$ & Costs & $\begin{array}{c}\text { Driver } \\
\text { level }\end{array}$ & Costs \\
\hline $\begin{array}{l}\text { Pollution prevention } \\
\text { activity }\end{array}$ & 44.44 & 1,500 & 66,660 & 1,200 & 53,328 \\
\hline Social activities & 17.65 & 1,000 & 17,650 & 2,400 & 42,360 \\
\hline $\begin{array}{l}\text { Resource recycling } \\
\text { activity }\end{array}$ & 4.8 & 30,000 & 144,000 & 45,000 & 216,000 \\
\hline $\begin{array}{l}\text { Environmental } \\
\text { remediation activities }\end{array}$ & 0.48 & 150,000 & 72,000 & 225,000 & 108,000 \\
\hline Total & - & - & 300,310 & - & 418,688 \\
\hline
\end{tabular}

Costs per unit of product are calculated by dividing the total costs for each activity by the total amount of products " $C$ " and "D". The total produced quantity of product "C" is 50,000 units, and product "D" 65,000 units. The calculation is given in Table 6.

Table 6.: Costs per unit of product

\begin{tabular}{|l|c|c|c|c|}
\hline \multirow{2}{*}{\multicolumn{1}{|c|}{ Activity }} & \multicolumn{2}{c|}{ Product ,C“ } & \multicolumn{2}{c|}{ Product,,D“ } \\
\cline { 2 - 5 } & Costs & Per unit & Costs & Per unit \\
\hline Pollution prevention activity & 66,660 & 1.33 & 53,328 & 0.82 \\
\hline Social activities & 17,650 & 0.35 & 42,360 & 0.65 \\
\hline Resource recycling activity & 144,000 & 2.88 & 216,000 & 3.32 \\
\hline Environmental remediation activities & 72,000 & 1.44 & 108,000 & 1.66 \\
\hline Total & $\mathbf{3 0 0 , 3 1 0}$ & $\mathbf{6}$ & $\mathbf{4 1 8 , 6 8 8}$ & $\mathbf{6 . 4 5}$ \\
\hline
\end{tabular}


After the calculation, we can perform an analysis of the structure of total costs. The total environmental costs amount to 718,998 m.u., of which product "C" takes 300,310 m.u., and product " $D$ " 418,688 m.u. The analysis of the cost structure by products is shown in Graph 1.

Graph 1.: The analysis of the cost structure by products

The cost structure by products

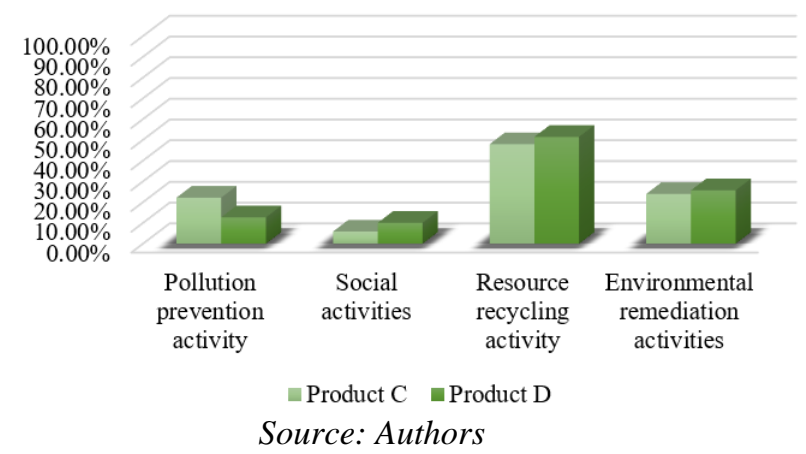

Environmental activity-based costing provides an opportunity for the company to see to what extent environmental costs reflect environmental damage. The results obtained show that the product "D" brings more environmental problems, because the environmental costs of this product are higher. Product " $\mathrm{C}$ " has lower environmental costs and they account for $41.77 \%$ of total costs. The activity cost per unit of product as a measure of the "purity" of a product indicates a product whose production process is "dirty" and is used to improve environmental performance and economic efficiency. Based on the above, product " $\mathrm{C}$ " provides more opportunities for environmental and economic improvements.

\section{ADVANTAGES AND DISADVANTAGES OF ENVIRONMENTAL ACTIVITY-BASED COSTING}

Environmental activity-based costing provides the company with the information it needs to adequately manage environmental costs. Environmental cost information is used for (Henri at al. 2013, p.650):

- Feedback - comparison of incurred environmental costs with planned amounts, analysis of deviations and decision-making regarding the implementation of corrective measures in case of negative deviations;

- Focusing attention - directing managers to those business segments that are critical from the aspect of environmental 
protection. At the same time, it points to the importance of environmental issues, the need to manage and reduce these costs;

- Decision-making - separate reporting on environmental costs enables their consideration when making decisions on sales prices, production mix, etc. In this way, arbitrariness in terms of overestimating/underestimating the costs of products and services is reduced, which may be a consequence of integrating environmental costs into a wider block of overhead costs.

$\mathrm{ABC}$ enables the linking of environmental costs and strategic management, the identification of key activities and the reliable allocation of activity costs to individual products. Based on the identification of environmental costs, this calculation recognizes and distinguishes products whose production process is "clean" and "dirty" and provides opportunities to discover the environmental and economic potential for improving the company's business. Information on environmental costs is relatively accurate, which contributes to the detection of toxic products and their responsibility for environmental costs. At all stages of the life cycle through a series of internal and external activities, costing provides the ability to track costs. In this way, companies can identify activities that add or do not add value to the product.

According to IFAC, Gibson, Martin, Vasile and Man (Gibson \& Martin, 2004; Vasile \& Man, 2012), the benefits of applying environmental management accounting and environmental costs are as follows:

- Identifying and measuring environmental costs - the company identifies costs within overhead costs using the EMA.

- More accurate allocation of costs to cost drivers conventional costing systems do not recognize environmental costs, and environmental costs are very often evenly distributed to places, activities and drivers even though they do not cause them.

- Contribution to a more realistic costing - more accurate cost allocation and control allows the cost to be more realistic.

- Improving the decision-making process - as the EMA also provides non-financial information, the company has a better information base for making business decisions.

- Discovering opportunities across the organization environmental cost analysis allows one to identify potential events that could lead to revenue generation (e.g. material reuse). 
- Contributing to higher competitive advantage - reducing environmental costs potentially improves the company's competitive advantage.

- Support for internal and external reporting on financial and environmental issues - financial and non-financial performance measures can help in compiling reports for internal and external reporting.

- Contribute to improving the company's reputation - EMA can improve the company's reputation with key stakeholders, especially if the company uses the information to reduce the negative impact on the environment and compile reports on sustainable development.

- Strengthening the ability to attract, motivate and retain employees - as a company strives to preserve the environment and reduce environmental costs, it can improve its ability to attract and retain quality staff and improve employee morale.

- Generating social benefits - the aforementioned benefits can be implemented here, as they lead to the creation of a cleaner environment, and thus to greater human and social benefits.

In addition to these advantages, there are disadvantages of environmental management accounting, such as the lack of clear business objectives (when it comes to environmental issues), insufficient commitment of management and lack of enthusiasm about the implementation of EABC. Inadequate activity-based costing design occurs due to the burden of detail, opacity, complexity, resistance to change and the risk of change such as detecting product unprofitability, inefficiency of activities, capacity underutilization. In order to successfully implement EABC, it is necessary to organize work in multifunctional teams, i.e. include employees of various professions such as management accountants, engineers, technologists, legal advisers, etc. The choice of wrong cost drivers, the difficult allocation of overhead costs to be attributed to a number of activities, the complexity of the methodology are also cited as shortcomings due to which the EABC cannot be universally applicable.

Thus, the previously explained concept produces very important information that the company can use when making decisions. Companies need to be environmentally responsible, to integrate environmental policy into corporate policy as well as to report on achieved environmental performance. All this is reflected in the sustainable development and improvement of the market and economic position of the company. 


\section{CONCLUSION}

By integrating the environmental component into conventional management accounting, environmental management accounting arises, whose information enables the company to reduce costs, improve competitive advantage, harmonize operations with legal regulations, environmental standards and build a good reputation. EMA integrates environmental requirements into its business strategy and thus provides the company with guidelines for sustainable development. EMA provides both financial and non-financial information of interest to various stakeholders.

The application of environmental management accounting for companies is of great importance. The information produced by environmental management accounting influences the improvement of resource efficiency, decision-making when choosing a specific project, more efficient environmental management processes.

The main challenge is the identification of environmental costs, as this is a category that is not viewed as independent, but as part of overhead costs. Therefore, companies must have good accounting support, i.e. a well-established environmental costing system.

Environmental management accounting and environmental costs lead companies to focus on preservation and environmental responsibility and to report on achieved performance. In that way, they can influence the sustainable development, but also the improvement of the market and economic position of the company.

\section{LITERATURE}

1. Bilbilovska, G. (2015). Input-output analiza u Makedoniji. Ekonomski pogledi, 17(3), 125-137.

2. Burritt, R. L. (2004). Environmental management accounting: roadblocks on the way to the green and pleasant land. Business Strategy and the Environment, 13(1), 13-32.

3. Cullen, D., \& Whelan, C. (2006). Environmental management accounting: the state of play. Journal of Business \& Economics Research (JBER), 4(10), 1-6.

4. Cokins, G. (1999). Using ABC to become ABM. Journal of Cost Management (January/February), 29-35.

5. Gibson, K. C., \& Martin, B. A. (2004). Demonstrating value through the use of environmental management accounting. Environmental quality management, 13(3), 45-52. 
6. Gray, R., \& Bebbington, J. (2001). Accounting for the Environment. Sage.

7. Henri, J. F., Boiral, O., \& Roy, M. J. (2013). The tracking of environmental costs: Motivations and impacts. European Accounting Review, 23(4), 647-669.

8. Hansen, R., \& Mowen, M. (2003). Cornerstones of Cost Management. South-Western, Cengage Learning.

9. Jovanović, D., Ljubisavljević, S., Ekološko računovodstvo $i$ revizija kao alati upravljanja zaštitom životne sredine, Scientific assembly 2017 "Uticaj globalizacije na upravljanje i ekonomski razvoj Šumadije i Pomoravlja", University of Kragujevac, Faculty of Economics, 2017 (pp. 521-530).

10. Jugović, J. (2019). Upravljanje troškovima ekološke zaštite u funkciji unapređenja konkurentnosti preduzeća. Ekonomske ideje $i$ praksa, (33), 43-59.

11. Radukić, S., \& Stevanović, T. (2011). Ekološki zahtevi i njihov računovodstveni tretman. Ekonomske teme, 49(1), 111-121.

12. Sekerez, V. (2016). Regulatorni okvir i kvalitet izveštavanja o održivom razvoju. Ekonomske ideje i praksa, (20), 53-68.

13. Schaltegger, S., \& Burritt, R. (2000). Contemporary Environmental Accounting - Issues, Concepts and Practice. Greenleaf Publishing Limited, Sheffield.

14. Tsai, W. H., Lin, T. W., \& Chou, W. C. (2010). Integrating activity-based costing and environmental cost accounting systems: a case study. International Journal of Business and Systems Research, 4(2), 186-208.

15. Vasile, E., \& Man, M. (2012). Current dimension of environmental management accounting. Procedia-Social and Behavioral Sciences, 62, 566-570.

Рад је примљен: 15. јануара 2021. Рад је прихваћен за штампу: 22. фебруара 2021. 